\title{
Antifungal efficacy of Moringa oleifera leaf and seed extracts against Botrytis cinerea causing gray mold disease of tomato (Solanum lycopersicum L.)
}

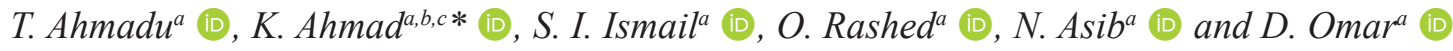 \\ ${ }^{a}$ Department of Plant Protection, Faculty of Agriculture, Universiti Putra Malaysia, Serdang, Selangor Darul Ehsan, Malaysia \\ 'Institute of Plantation Studies - IKP, Universiti Putra Malaysia, Serdang, Selangor Darul Ehsan, Malaysia \\ 'Institute of Tropical Agriculture and Food Security - ITAFoS, Universiti Putra Malaysia, Serdang, Selangor Darul Ehsan, Malaysia. \\ *e-mail: khairulmazmi@upm.edu.my
}

Received: January 20, 2020 - Accepted: August 20, 2020

(With 5 figures)

\begin{abstract}
Drawbacks associated with the use of chemical fungicides to control plant pathogenic fungi such as Botrytis cinerea stimulate the need for alternatives. Therefore, the present study was carried out to determine the antifungal potentials of Moringa oleifera extracts against $B$. cinerea. Phytochemical analysis using qualitative chemical tests revealed the presence of huge amount of crucial phytochemicals compounds like phenolic compounds, alkaloids and saponins in the $M$. oleifera leaf extract. Antifungal bioassay of the crude extracts indicated better mycelial growth inhibition by methanol leaf extract (99\%). The minimum inhibitory concentration (MIC) was $5 \mathrm{mg} / \mathrm{ml}$ with 100\% spore germination inhibition and minimum fungicidal concentration (MFC) was $10 \mathrm{mg} / \mathrm{ml}$ with $98.10 \%$ mycelial growth inhibition using broth micro dilution and poisoned food techniques. Gas chromatography-mass spectrometry (GC-MS) analysis led to the identification of 67 volatile chemical compounds in the leaf extract with 6-decenoic acid (Z)- (19.87\%) was the predominant compound. Further chemical elucidation of the crude extracts performed by liquid chromatography with tandem mass spectrometry (LC-MS/MS) showed the presence of non-volatile chemical compounds, mostly flavones, flavonoids and phenolic acids (i.e. quercetin and kaempferol). Scanning electron microscopy and transmission electron microscopy analysis showed positive effect of $M$. oleifera leaf extract on the treated conidia and mycelium of $B$. cinerea. Findings revealed that irreversible surface and ultra-structural changes with severe detrimental effects on conidia and mycelium morphology compared to control treatment. Overall findings suggested that $M$. oleifera leaf extract is a promising candidate for biological control of fungal pathogens, thus limiting overdependence on chemical fungicides.
\end{abstract}

Keywords: antifungal activity, Botrytis cinerea, Moringa oleifera, phytochemicals.

\section{Eficácia antifúngica de extratos de folha e de semente de Moringa oleifera contra Botrytis cinerea causador da doença do molde cinza de tomate (Solanum lycopersicum L.)}

\section{Resumo}

As desvantagens associadas ao uso de fungicidas químicos para controlar fungos fitopatogênicos, como Botrytis cinerea, estimulam a necessidade de alternativas. Portanto, o presente estudo foi realizado para determinar o potencial antifúngico de extratos de Moringa oleifera contra B. cinerea. A análise fitoquímica usando testes químicos qualitativos revelou a presença de uma grande quantidade de compostos fitoquímicos cruciais, como compostos fenólicos, alcaloides e saponinas no extrato da folha de $M$. oleifera. O bioensaio antifúngico dos extratos brutos indicou melhor inibição do crescimento micelial pelo extrato de folhas de metanol (99\%). A concentração inibitória mínima (MIC) foi de $5 \mathrm{mg} / \mathrm{mL}$ com $100 \%$ de inibição da germinação de esporos e a concentração fungicida mínima (MFC) foi de $10 \mathrm{mg} / \mathrm{mL} \mathrm{com}$ $98,10 \%$ de inibição do crescimento micelial usando microdiluição em caldo e técnicas de alimentos envenenados. A análise por cromatografia gasosa-espectrometria de massa (GC-MS) levou à identificação de 67 compostos químicos voláteis no extrato da folha, sendo o ácido 6-decenoico (Z) (19,87\%) o composto predominante. Elucidação química adicional dos extratos brutos realizada por cromatografia líquida com espectrometria de massa em tandem (LC-MS/MS) mostrou a presença de compostos químicos não voláteis, principalmente flavonas, flavonoides e ácidos fenólicos (ou seja, quercetina e kaempferol). As análises de microscopia eletrônica de varredura e microscopia eletrônica de transmissão mostraram efeito positivo do extrato de folhas de $M$. oleifera sobre os conídios e micélios tratados de $B$. cinerea. Os resultados revelaram a superfície irreversível e alterações ultraestruturais com graves efeitos prejudiciais sobre os conídios e a morfologia micelial, em comparação com o tratamento de controle. Os resultados gerais sugeriram que o extrato da folha de $M$. oleifera é um candidato promissor para o controle biológico de patógenos fúngicos, limitando assim a dependência excessiva de fungicidas químicos.

Palavras-chave: atividade antifúngica, Botrytis cinerea, Moringa oleifera, fitoquímicos. 


\section{Introduction}

Gray mold disease is caused by Botrytis cinerea Persoon: Fries [teleomorph: Botryotinia fuckeliana (de Bary) Whetzel] is a serious disease of tomato (Solanum lycopersicon L.) in Malaysia and in most areas of the world (Kim et al., 2016). The disease causes severe damage on fruits and vegetables at both pre- and post-harvest time. Botrytis cinerea is an ascomycetous fungus as well as a necrotrophic plant pathogen (Staats et al., 2005) that has been ranked second after Magnaporthe oryzae in the top 10 devastating fungal plant pathogens worldwide due to its broad host range (Shaw et al., 2016; Elad et al., 2016; Dean et al., 2012). The fungus is capable of infecting more than 200 plant species, including agriculturally important crop plants and harvested commodities, such as grapes, cucumbers, tomatoes, strawberries, cut flowers, bulb flowers, and ornamental plants (Parvu et al., 2010; Kars et al., 2005). The broad host range of $B$. cinerea leads to great economic losses, not only during crop growth but also during the storage and on transit of the harvested products (Elad, 2003). The fungus also kills it susceptible host cells by secreting lytic enzymes or toxic compounds and also produces an array of destructive enzymes and toxins that can conquer host defense mechanisms (Parvu et al., 2010; Makovitzki et al., 2007; Williamson et al., 2007). Gray mold occurs frequently in the tomato greenhouses in Cameron Highlands areas of Pahang in Malaysia resulting in reduced plant growth, premature leaves defoliation, fruit rot and consequently adverse effect on yields. Because of this, if the disease is not properly and effectively managed, it can be destructive enough to cause extensive yield losses leading to significant backwards in the tomato industries and/or tomato growers.

In a bid to control the disease, farmers depend on synthetic pesticides as their primary means for managing the disease, but the environment and human health have fared badly from the use of such synthetic chemicals. In addition, their use has been restricted due to their carcinogenicity, teratogenicity, high and acute residual toxicity, long degradation period, environmental pollution and possible side effects on human health through food chain (Hollomon, 2015; Ishii and Holloman, 2015; Enyiukwu et al., 2014; Aiying et al., 2011). In line with the public opinions and concerns related to the environmental and human safety, development of resistance by several strains of plant pathogens (i.e. B. cinerea) due to progressive use of such chemicals and increasing regulations on chemical pesticides use (Elliott et al., 2009), it is imperative to explore new alternatives that will reduce the overdependence on synthetic chemicals to manage the pathogen properly. Today, serious and much endeavours are put in place to give priority on pesticides of plant origin as there is a need to look for reliable and enduring solutions that care about the demands of man and environment (Taiga et al., 2008; Amadioha, 2002).

The plant world is rich store house of natural chemicals that could be exploited for use as biopesticides (Li Destri
Nicosia et al., 2016; Satish et al., 2007). Moringa oleifera is a medicinal plant that is now emerging as a safer and more compatible alternative to chemical fungicides. All parts of the plant including roots, flowers, bark, stem, leaves, seeds and essential oils possess antimicrobial properties and are therefore being used for medicinal and other purposes (Dwivedi and Enespa, 2012; Anwar et al., 2007). Chemical analysis of these morphological parts showed that they are containing a profile of important minerals, vitamins, protein and a large quantity of phytochemical compounds that have biological activity and can potentially be used to retard the effects of microorganisms (Arora and Onsare, 2014; Satish et al., 2013; Gurjar et al., 2012). Recent reports on phytochemical analysis of the $M$. oleifera leaf revealed the presence of various antioxidant compounds like ascorbic acid, fatty acids and phenolic acids (Vongsak et al., 2014; Alhakmani et al., 2013). Other compounds reported present in $M$. oleifera includes quercetin, zeatin, $\beta$-sitosterol, kaempferol, caffeoylquinic acid (Sharma and Paliwal, 2013) and myricetin, rutin, chlorogenic acid, glycosides niaziminin and niazin (Mbikay, 2012). These compounds are reported to possessed antimicrobial properties (Arora et al., 2014; Arora et al., 2013; Dwivedi and Enespa, 2012), antifungal (Batista et al., 2014; Kadhim and Al-Shammaa, 2014), antioxidant (Verma et al., 2009), antibacterial, antiulcer (Arora and Onsare, 2014; Belay and Sisay, 2014), anti-inflammatory, diuretic (Cáceres et al., 1992; Krishnamurthy et al., 2015) and anticancer (Pinto et al., 2015). Batista et al. (2014) and Gifoni et al. (2012) reported the antifungal inhibitory activity of Moringa-Chitin Binding Protein $\left(\mathrm{Mo}-\mathrm{CBP}_{3}\right)$ isolated and purified from the seeds of $M$. oleifera against mycelial growth and spore germination of Fusarium solani at minimum inhibitory concentration (MIC) concentration $\left(0.05 \mathrm{mgmL}^{-1}\right)$ with irreversible ultra-structural changes.

Although many reports are available on the efficacy of $M$. oleifera extracts as bio-fungicide against plants pathogenic fungi, further investigation are required to understand the $M$. oleifera extracts effect on $B$. cinerea. Therefore, the objectives of the present study were to carry out phytochemical analysis of methanolic leaf extract of $M$. oleifera, evaluate its antifungal activity against $B$. cinerea and examine the ultrastructural changes in $B$. cinerea conidia and mycelia at MIC concentration of M. oleifera methanolic leaf extract.

\section{Material and Methods}

\subsection{Plant materials}

The plant material (M. oleifera) was obtained from Demonstration Farm 2 of the Universiti Putra Malaysia (UPM), Selangor, Malaysia. The plant was taxonomically identified and confirmed by Dr. Shamsul Khamis from the Institute of Bioscience (IBS) Universiti Putra Malaysia (UPM), Malaysia. Voucher specimen (SK 3029/16) was deposited in the Herbarium of Biodiversity, Institute of Bioscience (IBS), Universiti Putra Malaysia (UPM), Malaysia. 


\subsection{Pure culture and spore preparation}

Pure culture $B$. cinerea isolates of $\mathrm{BCH} 02$ and $\mathrm{BCH} 07$ were used in the present study selected as the most virulent strains from the previous study (Tijjani et al., 2016). These isolates were previously isolated from infected tomato fruits with typical symptoms of gray mold disease from a greenhouse in Cameron Highlands, Pahang, Malaysia. The identities of the isolates were confirmed based on morphology; gene sequence analysis of the internal transcribed spacer (ITS) region and glyceraldehyde-3phosphate dehydrogenase (G3PDH). The gene sequences were deposited in the National Centre for Biotechnology Information (NCBI) database with the following accession number; KU992694 (BCH02) and KU992698 (BCH07) for ITS gene and KY201457 (BCH02) and KY201460 (BCH07) for G3PDH gene. The concentration of the conidial suspension used was adjusted to $10^{6}$ conidia/ml using Haemocytometer (Abd-Alla and Haggag, 2010).

\subsection{Preparation of plant extracts}

\subsubsection{Solvents extraction}

Organic solvents with different polarity were used for small-scale extraction which includes methanol, ethanol (polar), ethyl acetate (semi-polar) and hexane (non-polar) to determine the best solvent for extraction. The extraction was done by dissolving

$100 \mathrm{~g}$ of dry powdered leaf of $M$. oleifera into $500 \mathrm{ml}$ of methanol and ethanol in $1000 \mathrm{ml}$ conical flask each and then shaken with a mechanical shaker (Orbitron, infors HT Switzerland) for 72 hours to allow proper extraction. The macerates were filtered with Whatman's no. 1 filter paper $\left(\right.$ ALBERT $\left.^{\mathrm{R}}\right)$ after 3 days of immersion. The solvents were evaporated from the crude extracts to reduce the solvent concentration with a rotary evaporator (HahnShin Scientific Co., Taiwan). The semi-liquid crude extracts from the rotary evaporator flask were filtered with a sterilized 0.45 syringe filter (Sartouris ${ }^{\circledR}$ Syringe filters) to remove unwanted materials. Same procedure was followed for the powdered $M$. oleifera seed.

\subsubsection{Aqueous extraction}

This extraction was performed with water as the solvent by dissolving $100 \mathrm{~g}$ of dried leaf of M. oleifera in 1 litre of sterilized distilled water in 2 litre conical flasks, vigorously shaken and left for 24 hours at $28 \pm 2^{\circ} \mathrm{C}$. After 24 hours, the mixture was filtered with two layered muslin's cheese cloth. The obtained filtrate was then centrifuge at $6000 \mathrm{rpm}$ for 15 minutes (Avanti J-26 XPI centrifuge, Beekman Coulter, USA). The supernatant collected was filtered again with a Whatman's no. 1 filter paper (ALBERT ${ }^{\mathrm{R}}$ ) and then followed by dry-freezing at $54^{\circ} \mathrm{C}$ in 010 vacuum mbar with a modulyod freeze drier (Valupump VLP). The crude extracts were filtered with a sterilized 0.45 syringe filter (Sartouris ${ }^{\circledR}$ Syringe filters) to remove unwanted materials. The final material was maintained in sterile airtight glass bottles and stored in a refrigerator at $4^{\circ} \mathrm{C}$. Same procedure was followed for the powdered $M$. oleifera seed.
The percentage yield of the crude extracts was calculated following the method of Mushore and Matuvhunye (2013) (Formula 1) below:

$\%$ of yield weight $=\frac{\left(\mathrm{W}_{2}\right)-\left(\mathrm{W}_{1}\right)}{\left(\mathrm{W}_{0}\right)} \times 100$

Where: $\mathrm{W}_{0}$ : weight of initial dried sample

$\mathrm{W}_{1}$ : weight of empty flask

$\mathrm{W}_{2}$ : weight of the extract and flask

\subsection{Antifungal bioassay}

Poisoned food technique was used to screen the best plant solvent extract. Ten different plant solvent fractions were screened viz: Moringa leaf methanol extract (MLM), Moringa leaf ethanol extract (MLE), Moringa leaf ethyl acetate extract (MLEA), Moring $a$ leaf hexane extract (MLH), Moringa leaf distilled water extract (MLDW), Moringa seed methanol extract (MSM), Moringa seed ethanol extract (MSE), Moringa ethyl acetate extract (MSEA), Moringa seed hexane extract (MSH) and Moringa seed distilled water extract (MSDW). Potato dextrose agar (PDA) plates were amended, with $100 \mathrm{mg} / \mathrm{ml}$ of plant extracts from each solvent. The mixture was swirled to enhance efficient miscibility of the agar and the extracts. Five-day old fungal cultures of $B$. cinerea isolates (BCH02 and $\mathrm{BCH} 07)$ isolates were aseptically punched with a sterile cork borer of $6 \mathrm{~mm}(0.6 \mathrm{~cm})$ diameter and the fungal discs were placed at the centre of PDA gelled plates. Perpendicular lines were drawn at the bottom of each plate and the point of intersection was taken as the centre of the plate to ease precise measurement. The plates were incubated at $28^{\circ} \mathrm{C}$ for $5-7$ days until the control plates were filled. The diameter of the colony was recorded on daily basis by measuring the two paradoxical circumference of the colony growth along the lines drawn at the bottom of each plate. Percentage inhibition of radial mycelial growth (PIGR) was evaluated by measuring the colony diameter of plates with plant extract (poisoned plates) and plate with solvent (non-poisoned plates) and calculated using Formula 2 given below:

$\mathrm{PIRG}=\frac{\mathrm{R}_{1}-\mathrm{R}_{2}}{\mathrm{R}_{1}} \times 100$

Where: $\mathrm{R}_{1}$ : average measurement in the control $\mathrm{R}_{2}$ : average measurement in the treatment

\subsection{Determination of minimum inhibitory concentration (MIC) and minimum fungicidal concentration (MFC)}

\subsubsection{Minimum inhibitory concentration (MIC)}

The minimum inhibitory concentration (MIC) of the crude extract was determined following the method of Broekaert et al., (1990) using broth micro-dilution technique or microtitre plate (96 wells). Potato dextrose broth (PDB), $\left(\right.$ Difco $^{\mathrm{TM}}$, Becton, USA) was prepared $24 \mathrm{~g} / 1$, autoclaved at $121^{\circ} \mathrm{C}$ for $15 \mathrm{~min}$ and used for the determination of the MIC. Ten different concentrations ranging from $50 \mathrm{mg} / \mathrm{ml}-5 \mathrm{mg} / \mathrm{ml}$ were screened along with benomyl $(0.2 \mathrm{mg} / \mathrm{ml})$ as a standard 
control practice (SCP). In each well, $100 \mu \mathrm{l}$ of PDB, $50 \mu 1$ of plant extract and $40 \mu$ l of fungal spore suspension $(1 \times$ $10^{6}$ spore concentration $\mathrm{ML}^{1}$ ) were loaded. For SCP $50 \mu 1$ of benomyl was loaded and $50 \mu \mathrm{l}$ of methanol for the negative control instead of plant extract. Treatments were replicated three times and arranged in completely randomize design. The plates were incubated for 24 hours at $37^{\circ} \mathrm{C}$ (Lourens et al., 2004). Measurements were taken at $620 \mathrm{~nm}$ using spectrophotometric microtitre plate reader (MULTI SKAN GO). Growth inhibition (PGI) was determined based on the Formula 3 below:

$\mathrm{PGI}=\frac{\Delta \mathrm{C}-\Delta \mathrm{T}}{\Delta \mathrm{C}} \times 100$

Where: $\Delta \mathrm{C}$ : corrected absorbance of the control micro culture at $620 \mathrm{~nm}$

$\Delta \mathrm{T}$ : corrected absorbance of the treatment micro culture at $620 \mathrm{~nm}$

\subsubsection{Minimum fungicidal concentration (MFC)}

Poisoned food technique was used to determine minimum fungicidal concentration (MFC). Potato dextrose agar (Difco ${ }^{\mathrm{TM}}$, Becton, USA) was prepared $39 \mathrm{~g} / \mathrm{l}$, autoclaved at $121^{\circ} \mathrm{C}$ for $15 \mathrm{~min}$ and used for the determination of the MFC. Ten different concentrations ranging from $100 \mathrm{mg} / \mathrm{ml}-10 \mathrm{mg} / \mathrm{ml}$ diluted from the stock crude extract were tested along with benomyl $(0.2 \mathrm{mg} / \mathrm{ml})$ as a SCP and distilled water as a negative control. About $15 \mathrm{ml}$ of the PDA was poured into each petri plate and prior to solidification each concentration of the extract was incorporated into each plate, gently swirled to obtain uniform miscibility of agar and the extract. Then 5-days-old fungal cultures of $B$. cinerea isolates ( $\mathrm{BCH} 02$ and $\mathrm{BCH} 07$ ) isolates were aseptically punched with a sterile cork borer of $6 \mathrm{~mm}$ diameter and the fungal discs were placed at the centre of PDA gelled plates. Perpendicular lines were drawn at the bottom of each plate and the point of intersection was taken as the centre of the plate to ease precise measurement. The plates were incubated at $28^{\circ} \mathrm{C}$ for $5-7$ days until the control plates were filled. The diameter of the colony was recorded on daily basis by measuring the two paradoxical circumferences of the colony growth along the lines drawn at the bottom of each plate. Percentage inhibition of radial mycelial growth was evaluated by measuring the colony diameter of plates with plant extract (poisoned plates) and plate with solvent (non-poisoned plates) and calculated using the Formula 4 given below:

$\mathrm{PIRG}=\frac{\mathrm{R}_{1}-\mathrm{R}_{2}}{\mathrm{R}_{1}} \times 100$

Where: $\mathrm{R}_{1}$ : average measurement in the control $\mathrm{R}_{2}$ : average measurement in the treatment

\subsection{Phytochemical analysis of M. oleifera methanol leaf extracts}

\subsubsection{Preliminary qualitative tests}

Crude methanolic leaf extract of $M$. oleifera was subjected to preliminary phytochemical analysis using chemical tests for qualitative detection of the presence of phytochemical compounds including alkaloids, flavonoids, tannin, saponin, phenolic compounds, terpenoid, triterpenoids, steroids, and anthraquinone. The summary of the procedures for the chemical tests was shown in Table 1.

\subsubsection{Gas chromatography-mass spectrometry \\ (GC-MS) analysis for volatile compounds}

The method of Gao et al. (2014) was followed to perform the GC-MS analysis for volatile compounds present in the methanolic leaf extracts of $M$. oleifera. Briefly, Shimadu QP-2010 GC-MS system that consist of gas chromatograph interfaced with mass spectrometer and equipped with a Zebron ZB5-MS capillary fused silica column $(30 \mathrm{~m} \times 0.25 \mathrm{~mm}$ I.D. $\times 0.25 \mathrm{~m}$ film thickness $)$ was used for the analysis. The oven temperature was started from $70^{\circ} \mathrm{C}$ (isothermal for $3 \mathrm{~min}$ ), with an adjustment of $10^{\circ} \mathrm{C} / \mathrm{min}$, to $240^{\circ} \mathrm{C}$, ending with $10 \mathrm{~min}$ isothermal at $300^{\circ} \mathrm{C}$. Mass spectra were taken at $70 \mathrm{eV}$; a scan interval of 0.5 seconds and fragments from 40 to $440 \mathrm{Da}$. Total $\mathrm{GC}$ running time is $40 \mathrm{~min}$. Other running conditions used were as follows: carrier gas, helium $(99.999 \%)$, with a flow rate of $1 \mathrm{ml} / \mathrm{min}$; injection volume of $1 \mu \mathrm{l}$ was used with split ratio of $10: 1$, injector temperature, $250^{\circ} \mathrm{C}$. Mass spectra were taken at $70 \mathrm{eV}$; a scan interval of 0.5 seconds and fragments from 40 to $440 \mathrm{Da}$. Total GC running time is $40 \mathrm{~min}$. The mass spectrum of the obscured constituents was compared with those stored in the National Institute of Standards and Technology (NIST) Mass Spectral Library built up by using pure substances and the mass spectra from the published literature. The compound's name, percentage, retention time, molecular formula, molecular weight and chemical structure of the materials were established. GC-17A version 3 programming software was utilized to handle the mass spectra and chromatogram.

\subsubsection{Liquid chromatography with tandem mass} spectrometry (LC-MS/MS) analysis for non-volatile compounds

Liquid chromatography with tandem mass spectrometry (LC-MS/MS) analysis was performed using an AB Sciex 5500Q Trap (Linear Quadrupole Hybrid Ion Trap Mass Spectrometer, AB Sciex, Toronto, Canada) mass spectrometer operating in electrospray ionization (ESI) negative mode and hyphenated with an Agilent 1290 ultrahigh liquid chromatography system. The high purity gas for the mass spectrometer was set at 40 psi gas source, 40 psi for the heating gas and for collision gas with a source temperature of $500^{\circ} \mathrm{C}$. The setting for electrospray ionization voltage was set to $4500 \mathrm{kV}$. The collision energy to attain fragmentation was set at $35 \mathrm{eV}$ with a spread of $+/-15 \mathrm{eV}$. Mass range for MS/MS scan was set from $50-1000 \mathrm{~m} / \mathrm{z}$ while mass range for full scan was set from $100-1000 \mathrm{~m} / \mathrm{z}$ while scan speed was set at $1000 \mathrm{~m} / \mathrm{z}$ per second. A Phenomenex Synergy Fusion RP (100 mm $\times$ $2.1 \mathrm{~mm}$ i.d., $3 \mu \mathrm{m}$ particle size, Phenomenex, CA, USA) was used to obtain separation. The mobile phase was made up of aqueous ammonium formate $(5 \mathrm{mmol} / \mathrm{L})$ with $0.1 \%$ 
Table 1. Chemical tests for some phytochemical compounds from methanolic leaves extracts of M. oleifera.

\begin{tabular}{|c|c|c|c|}
\hline $\begin{array}{l}\text { Phytochemical } \\
\text { compound }\end{array}$ & Test type & Procedure & Reference \\
\hline Tannins & $\begin{array}{l}\text { Ferric chloride } \\
\text { test }\end{array}$ & $\begin{array}{l}\text {-About } 0.5 \mathrm{~g} \text { of methanolic extract was dissolved into } \\
10 \mathrm{ml} \text { of distilled water and filtered. } \\
-4-6 \text { drops of } 10 \% \text { ferric chloride was then added } \\
\text { into the filtrate. }\end{array}$ & (Harbone, 2001) \\
\hline Alkaloids & $\begin{array}{l}\text { Dragendorff's } \\
\text { test }\end{array}$ & $\begin{array}{l}\text { - Methanolic extract }(0.2 \mathrm{~g}) \text { was put into a conical } \\
\text { flask, followed by the addition of } 20 \mathrm{ml} \text { of sulphuric } \\
\text { acid diluted in methanol. } \\
\text { - The mixture was then filtered and treated with } 2 \\
\text { drops of Dragendorff's reagents (Potassium bismuth } \\
\text { iodide solution). }\end{array}$ & $\begin{array}{l}\text { (Ghani, 1998; } \\
\text { Harbone, 2001). }\end{array}$ \\
\hline Flavonoids & Ammonium test & $\begin{array}{l}\text {-About } 10 \mathrm{ml} \text { of ethyl acetate was added to } 0.2 \mathrm{~g} \text { of } \\
\text { the extract and heated in water bath for } 4 \mathrm{~min} \text {. } \\
\text {-The mixture was allowed to be cooled and then } \\
\text { filtered. } \\
\text { - } 1 \mathrm{ml} \text { of diluted ammonia was shaken with } 4 \mathrm{ml} \text { of } \\
\text { the filtrate and the layers were allowed to separate. }\end{array}$ & $\begin{array}{l}\text { (Harbone, 2001; } \\
\text { Sofowora, 2005)' }\end{array}$ \\
\hline Saponnins & Froth test & $\begin{array}{l}\text {-About } 20 \mathrm{ml} \text { of water was added to } 0.25 \mathrm{~g} \text { of the } \\
\text { extract in } 100 \mathrm{ml} \text { beaker, boiled and then filtered. } \\
\text {-The filtrate }(5 \mathrm{ml}) \text { was diluted with } 20 \mathrm{ml} \text { of distilled } \\
\text { water and shaken vigorously. } \\
\text {-This was the allowed to stand. }\end{array}$ & $\begin{array}{l}\text { (Harbone, 2001; } \\
\text { Khalil et al., 2013; } \\
\text { Sofowora, 2005). }\end{array}$ \\
\hline $\begin{array}{l}\text { Steroids/ } \\
\text { Triterpenoids }\end{array}$ & $\begin{array}{l}\text { Liebermann- } \\
\text { Burchardt test. }\end{array}$ & $\begin{array}{l}\text {-Methanolic extract }(1 \mathrm{ml}) \text { was boiled with } 2 \mathrm{ml} \text { of } \\
\text { chloroform and allowed to cool. } \\
\text {-Then 1-3 drops of concentrated sulphuric acid were } \\
\text { added, shaken and allowed to stand. }\end{array}$ & (Khalil et al., 2013). \\
\hline $\begin{array}{l}\text { Phenolic } \\
\text { compounds } \\
\text { Anthraquinone }\end{array}$ & $\begin{array}{l}\text { Ferric chloride } \\
\text { test } \\
\text { Borntrager's test }\end{array}$ & $\begin{array}{l}-3 \text { drops of } 1 \% \text { ferric chloride was added to } 3 \mathrm{ml} \\
\text { portion of methanolic extract. } \\
-10 \mathrm{ml} \text { of benzene was added to } 4 \mathrm{~g} \text { of the methanol } \\
\text { extract, shaken and filtered. } \\
\text {-Then } 5 \mathrm{ml} \text { of } 10 \% \text { ammonia solution was added to } \\
\text { the filtrate, shaken and allowed to stand. }\end{array}$ & $\begin{array}{l}\text { (Harbone, 2001: } \\
\text { Khalil et al., 2013). } \\
\text { (Kadhim and Al- } \\
\text { Shammaa, 2014). }\end{array}$ \\
\hline Terpenoids & Salkowski test & $\begin{array}{l}\text {-The extract }(2 \mathrm{ml}) \text { was dissolved in chloroform }(2 \mathrm{ml}) \\
\text { and then evaporated to dryness. } \\
\text {-Sulphuric acid }(2 \mathrm{ml}) \text { was added and boiled for } 2 \\
\text { minutes. }\end{array}$ & $\begin{array}{l}\text { (Kadhim and Al- } \\
\text { Shammaa, 2014; } \\
\text { Khalil et al., 2013). }\end{array}$ \\
\hline
\end{tabular}

formic acid (solvent $\mathrm{A}$ ) and acetonitrile with ammonium formate $(5 \mathrm{mmol} / \mathrm{L})$ with $0.1 \%$ formic acid (solvent $\mathrm{B}$ ). The compounds were separated with the following linearprogrammed solvent gradient: 0 minute $(10 \%), 10$ minutes $(95 \% \mathrm{~B}), 2$ minutes $(95 \% \mathrm{~B})$ then equilibrating to $10 \%$ $\mathrm{B}$ for 3 minutes. The flow rate for the column was set at $0.25 \mathrm{~mL} / \mathrm{min}$ while the column temperature was set at $40^{\circ} \mathrm{C}$ and injection volume at $10 \mu 1$.

\subsection{Scanning electron microscopy (SEM) and transmission electron microscopy (TEM) analysis}

\subsubsection{Scanning electron microscopy (SEM) analysis}

Scanning electron microscopy (SEM) was performed to determine the antifungal efficacy of the plant extracts (crude methanolic extract of $M$. oleifera) on the structural integrity of $B$. cinerea cells at the surface level. The samples of the test fungus were prepared for SEM examination following the method described by Hasan et al. (2014), starting from primary fixation to coating and finally viewing. First, the samples were cut $\left(1 \mathrm{~cm}^{3}\right)$ from the margin of actively growing PDA fungal culture treated with plant extract using a sterilized razor blade. The samples were then fixed with modified Karnovsky's fixative (Karnovsky, $1965)$ containing $2 \%(\mathrm{v} / \mathrm{v})$ glutaraldehyde and $2 \%(\mathrm{v} / \mathrm{v})$ paraformaldehyde in $0.05 \mathrm{M}$ sodium cacodylate buffer solution ( $\mathrm{pH} 7.2$ ) and left at $4^{\circ} \mathrm{C}$ overnight. The samples were washed with $0.1 \mathrm{M}$ sodium cacodylate buffer in 3 changes after (30 mins.) each, followed by post-fixation in $1 \%$ osmium tetroxide in $0.2 \mathrm{M}$ PBS for 2 hours, dehydrated through series of graded acetone $(35,50,75$, $95 \%$ ) for 10 minutes each and $100 \%$ for 15 minutes. After 
this, the specimens were stick on to stub with double tape, critical point dried in $\mathrm{CO}_{2}$, gold-coated using sputter ion coater $(5-10 \mathrm{~nm})$ and observed with a scanning electron microscope (SEM: JSM-5610LV, JOEL, Japan) at the IBS, University Putra Malaysia.

\subsubsection{Transmission electron microscopy (TEM) Analysis}

Transmission electron microscopy (TEM) was performed to confirm the SEM finding and also to determine the ultrastructural changes on the $B$. cinerea cells as a result of exposure to crude methanolic extract of $M$. oleifera. The samples of the test fungus were prepared for TEM examination following the method described by Sasidharan et al. (2012), starting from primary fixation to staining and finally viewing. The specimens were cut $\left(1 \mathrm{~mm}^{3}\right)$ from the margin of actively growing PDA fungal culture treated with plant extract using a sterilized razor blade. The samples were then fixed with modified Karnovsky's fixative (Karnovsky, $1965)$ containing $2 \%(\mathrm{v} / \mathrm{v})$ glutaraldehyde and $2 \%(\mathrm{v} / \mathrm{v})$ paraformaldehyde in $0.05 \mathrm{M}$ sodium cacodylate buffer solution ( $\mathrm{pH} 7.2)$ and left at $4{ }^{\circ} \mathrm{C}$ overnight. The samples were washed with $0.1 \mathrm{M}$ sodium cacodylate buffer in 3 changes after ( 30 mins.) each, followed by post-fixation in $1 \%$ osmium tetroxide in $0.2 \mathrm{M}$ PBS for 2 hours, dehydrated through series of graded acetone $(35,50$, $75,95 \%$ ) for 10 minutes each and $100 \%$ for 15 minutes. The specimens were infiltrated with acetone and resin mixture at the ratio of 1:1 for 4 hours, 1:3 overnight and $100 \%$ resin overnight again. After infiltration, the specimens were embedded in beam capsules filled with Spurr's resin. Ultra-thin sections (approximately $1 \mu \mathrm{m}$ in thickness) of the specimens were cut with a glass/ diamond knife using an ultra-microtome. The sections were mounted on copper grids and were stained with $2 \%$ uranyl acetate and Reynolds' lead citrate (Reynolds, 1963) for 10 min each. Finally, the sections were observed or viewed with a transmission electron microscope (TEM MODEL JEM 2100 field emission electron microscope (Japan Electron Optics Laboratory Co., Tokyo, Japan) in IBS, University Putra Malaysia.

\section{Results}

\subsection{Effect of solvents on the percentage extraction yield}

From our results it is evident that the analysis of the percentage yield of the crude extracts obtained from M. oleifera leaf and seeds with different solvents showed that methanol gave the highest yield $(14.16 \%)$ from leaf (Table 2), followed by ethanol (10.23\%) and the lowest yield was observed in distilled water (1.71\%). Similarly, in the seeds, methanol gave the highest yield (11.54\%), followed by ethanol $(6.41 \%)$ and the lowest yield was observed in hexane (1.27\%). Methanol solvent gave the highest yield compared to other solvents.

\subsection{Antifungal bioassay and determination of MIC and MFC of the plant extracts}

Figure 1 presented the results of antifungal bioassay of different solvent crude extracts from both $M$. oleifera leaf and seeds. The results indicated that, methanol crude extracts from both $M$. oleifera leaf and seeds gave better growth inhibition than other solvents. The highest growth inhibition was observed under both isolate $\mathrm{BCH} 02(>99.00 \%)$ and $\mathrm{BCH} 07$ ( $>99.00 \%)$ by methanol leaf extract, $99.00 \%$ in isolates $\mathrm{BCH} 07$ by methanol seed extracts, followed by $98.00 \%$ growth inhibition by ethanol leave and seed extracts as observed in both isolates. However, the lowest growth inhibition was observed in MSDW (28.00\%) under isolate BCH07. All extracts irrespective of plant part (leaves or seeds) inhibit fungal mycelial growth compared to the control.

MIC and MBC of M. oleifera were determined against $\mathrm{BCH} 02$ and $\mathrm{BCH} 07$ isolates of $B$. cinerea (Table 3). Methanol leaf extracts of M. oleifera showed the best performance in terms of MIC and MFC against the isolates. Both isolates (BCH02 and $\mathrm{BCH} 07$ ) had their most sensitivity to methanol leaf extracts of $M$. oleifera, which showed the MIC to be $5 \mathrm{mgml}^{-1}$ and MFC $10 \mathrm{mgml}^{-1}$. These results suggested that the antifungal compounds activity of $M$. oleifera is mainly concentrated in the leaf.

\subsection{Phytochemical profiling}

\subsubsection{Preliminary phytochemical analysis}

The preliminary phytochemical analysis of the methanolic leaves extract of $M$. oleifera carried out with various

Table 2. Extraction yield percentage of $M$. oleifera crude extracts from different solvents.

\begin{tabular}{ccc}
\hline Part of plant & Solvents & Percentage yield (\%). \\
\hline Leaf & Methanol & 14.16 \\
& Ethanol & 10.23 \\
& Ethyl acetate & 5.24 \\
& Hexane & 2.3 \\
Seed & Distilled water & 1.71 \\
& Methanol & 11.54 \\
& Ethanol & 6.41 \\
& Ethyl acetate & 3.43 \\
& Hexane & 1.27 \\
\hline
\end{tabular}




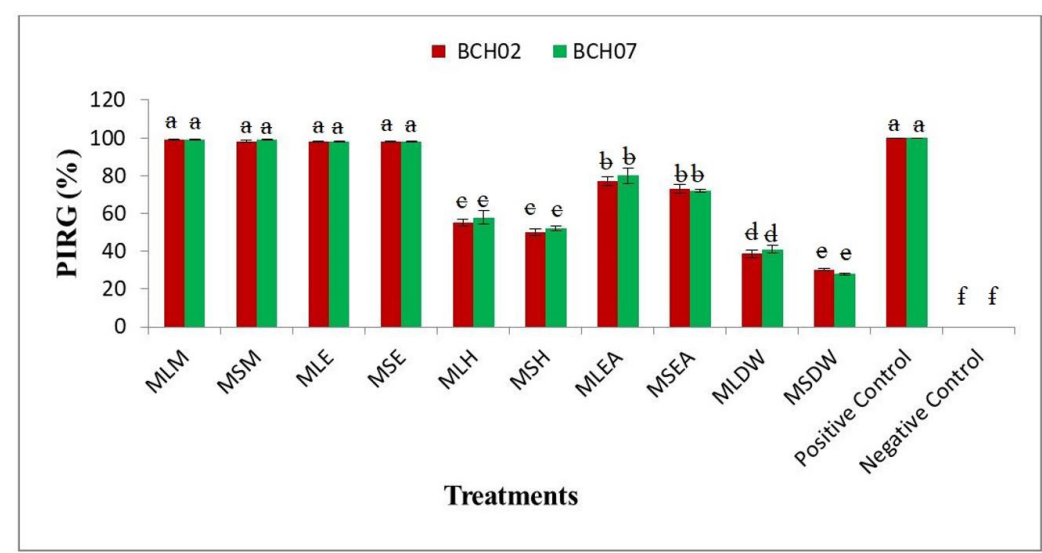

Figure 1. The percentage inhibition of radial mycelial growth (PIRG) of antifungal bioassay activities of different extracts of $M$. oleifera on two B. cinerea isolates. Means followed by the same letters within each chart's column are not significantly different at $\mathrm{P} \leq 0.05$ according to Turkey Studentized Range (HSD) Test.

Table 3. Minimum inhibitory concentration and minimum fungicidal concentrations of $M$. oleifera leaf extracts against B. cinerea isolate $\left(\mathrm{mgml}^{-1}\right)$

\begin{tabular}{|c|c|c|c|c|c|}
\hline \multirow{2}{*}{ Part of plant } & \multirow{2}{*}{ Solvent } & \multicolumn{2}{|c|}{ ВСН02 } & \multicolumn{2}{|c|}{ ВСН07 } \\
\hline & & MIC & MFC & MIC & MFC \\
\hline \multirow[t]{2}{*}{ Leaf } & Methanol & 5.00 & 10.00 & 5.00 & 10.00 \\
\hline & Ethanol & 10.00 & 20.00 & 15.00 & 30.00 \\
\hline \multirow[t]{2}{*}{ Seed } & Methanol & 10.00 & 10.00 & 10.00 & 10.00 \\
\hline & Ethanol & 15.00 & 20.00 & 15.00 & 30.00 \\
\hline
\end{tabular}

Table 4. Chemical tests for phytochemical compounds of methanol leaf extracts of M. oleifera.

\begin{tabular}{lllc}
\hline \multicolumn{1}{c}{$\begin{array}{c}\text { Phytochemical } \\
\text { compound }\end{array}$} & \multicolumn{1}{c}{ Chemical/colour tests } & \multicolumn{1}{c}{ Results/observations } & Inferences \\
\hline Tannins & Ferric chloride test & -Greenish black colour & + \\
Alkaloids & Dragendorff's test & -Development of an orange colour & + \\
Flavonoids & Ammonium test & -Yellow colour in bottom layer & + \\
Saponnins & Froth test & -Stable froth on standing & + \\
Steroids/ Triterpenoids & Liebermann-Burchardt test. & -Red colour top and yellow colour on bottom & + \\
Phenolic compounds & Ferric chloride test & - Development of violet or dark blue colour & + \\
Anthraquinone & Borntrager's test & - Development of red colour & + \\
Terpenoids & Salkowski test & -Formation of red colour at the lower & + \\
& & layer indicates the presence of Steroids & \\
\hline
\end{tabular}

$+=$ indicates the presence of phytochemical compounds.

chemical or colour tests for qualitative detection of the presence of phytochemical compounds were presented in (Table 4). Our analysis revealed the presence of alkaloids, flavonoids, tannin, saponin, phenolic compounds, terpenoid, triterpenoids, steroids, and anthraquinone in M. oleifera. The presence of the phytochemical compounds indicated the antifungal potentials of $M$. oleifera.

\subsubsection{Active compounds profiling using GC-MS}

The chemical compounds present in the crude methanol leaves extract of $M$. oleifera were identified by GC-MS analysis. A total of 67 different components were identified and the chromatogram of the components with their peaks was shown in Figure 2. The active principal components with higher peak percentages were 6-decenoic acid (Z)- (19.87\%), 2-dimethyl (trimethylsilylmethyl) silyloxymethyltetrahydrofuran
(11.90\%), beta.-1-rhamnofuranoside (11.07\%), malonic acid (6.22\%), n-hexadecanoic acid (5.87\%), 1,3-propanediol (3.77\%), benzeneacetonitrile (3.12\%), octadecanoic acid/ Stearic acid (2.95\%), 1,2,3,5-cyclohexanetetrol (2.38\%), docosanoic acid (2.24\%), cyclohexanecarboxylic (2.20\%), 2-furancarboxaldehyde (2.14\%) and 2,3-dihydro-3,5dihydroxy-6-methyl-4H-pyran-4-one $(2.11 \%)$. Their retention time (RT), molecular weight (MW), molecular formula, and chemical structure were presented in Table 5. The volatile chemical components, their chemical groups and biological activity were also presented in Table 6 .

Active compounds profiling using LC-MS/MS

In an analysis conducted with LC-MS/MS to determine the non-volatile components available in the methanol leaf extract of $M$. oleifera, it is evident that methanol crude leaf 


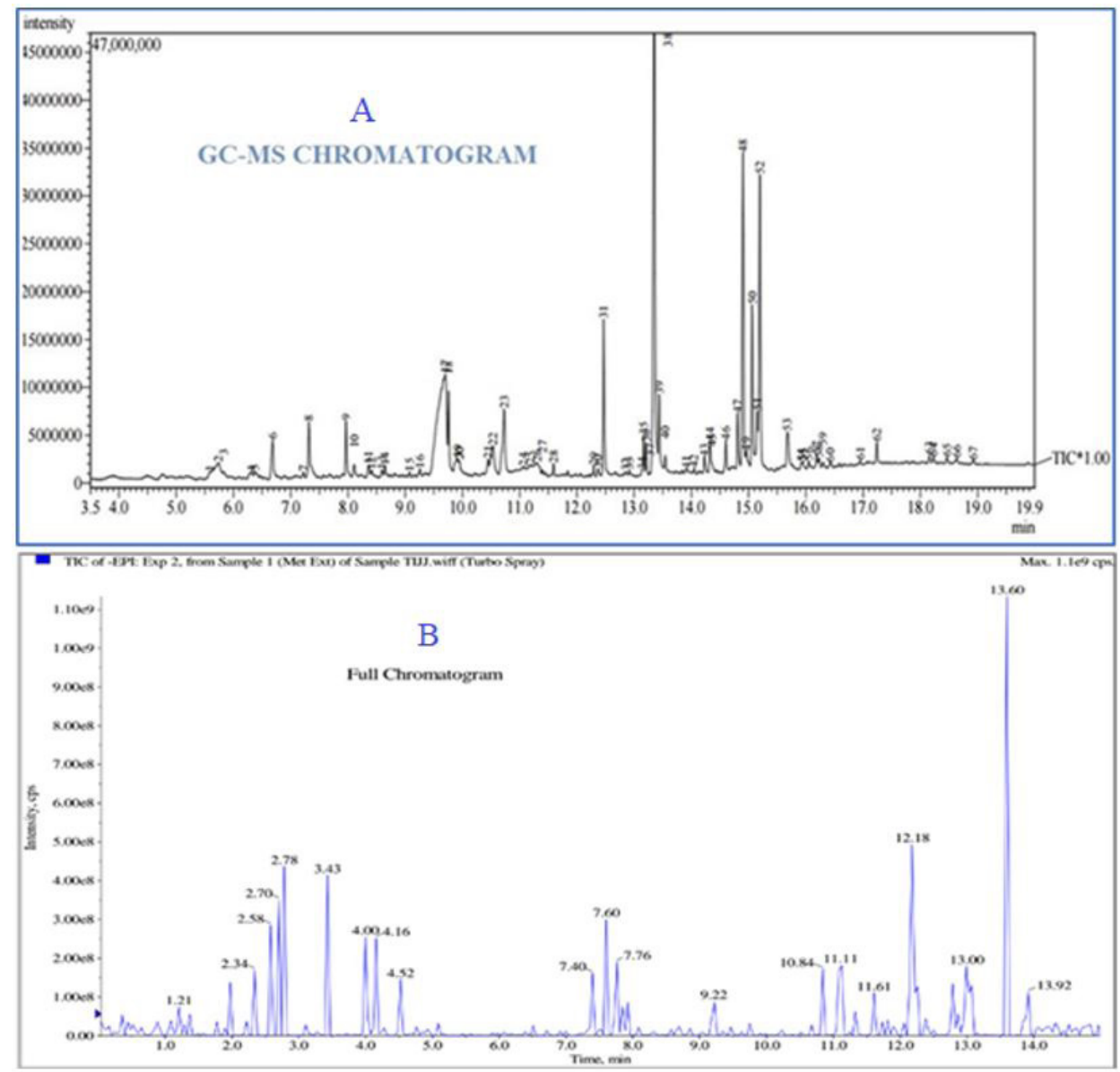

Figure 2. Chromatogram of methanol leaf extracts of M. oleifera. (A) GC-MS chromatogram of volatile active compounds. (B) LC-MS/MS chromatogram of non-volatile active compounds.

extract of $M$. oleifera was containing some non-volatile chemical compounds as presented in Table 7. The results of the analysis revealed the presence of phenylvaleric acid, caffeic acid, quinic acid, apigenin-6,8-di-C- $\beta$-Dglucopyranoside, apigenin $6 \mathrm{C}$ glucoside, quercetin-3O-glucoside dimer and kaempferol 3-o glucoside dimer as the predominant compounds and their retention time, molecular formula and molecular weight were given also in Table 7. The peaks in the LC-MS/MS chromatogram (Figure 2) confirmed the presence of compounds due to the large amounts of peaks in the chromatography.

Effect of methanol leaf extract of M. oleifera on the surface and ultrastructure of $B$. cinerea examined with SEM and TEM

\subsection{Observation with SEM}

Examination of the changes on the mycelium and conidia of $B$. cinerea treated with $M$. oleifera methanol leaf extract at MIC concentration through SEM micrographs revealed that $M$. oleifera have caused severe detrimental effects on the morphology of both mycelium (Figure 3b, c and d) and the conidia (Figure $4 b$ and c) compared to the controls (Figure $3 \mathrm{a}$ and $4 \mathrm{a}$ ). The effects observed include abnormal growth, lysis, shrinkage, disruption, aggregation, reduced hyphal length and diameters and pore formation on both mycelium (Figure 3b, c and d) and spores (Figure 4b and c) of the samples treated with crude methanol leaves extracts. The control treatments micrograph for mycelium (Figure 3a) and spore (Figure 4a) were observed with normal growth and smooth surfaces.

\subsection{TEM observation}

Figures 5a-d presented the results of TEM on the effect of $M$. oleifera methanol leaf extract at MIC concentration. The results showed that the untreated conidium of $B$. cinerea (control) grew normally with the ultra-structural components (Figure 5a). The TEM micrographs for the control conidium appeared with a regular cell wall of about 300 to $400 \mathrm{~nm}$ (thickness) having a two-layer structure, plasmalemma, cytosol (cytoplasm matrix) with nucleus and nucleolus, lipids; mitochondria and vacuole. The external layer of the cell wall was thin and electrodense; thick inner wall, less and uniform electrodense. The plasmalemma tightly adhered to the cell wall. The cytosol was distributed uniformly, and the nucleus was spherical. The mitochondria were usually ovoid, numerous and had an average electron density. Lipid and glycogen 
Table 5. Various volatile compounds identified in methanol leaf extracts of $M$. oleifera by GC-MS

\begin{tabular}{|c|c|c|c|c|c|c|}
\hline $\begin{array}{l}\text { Peak } \\
\text { No. }\end{array}$ & $\begin{array}{c}\text { RT } \\
(\mathrm{min})\end{array}$ & $\begin{array}{l}\text { Height } \\
(\%)\end{array}$ & Chemical compound & $\begin{array}{c}\text { Molecular } \\
\text { weight (g/mol) }\end{array}$ & $\begin{array}{l}\text { Molecular } \\
\text { formula }\end{array}$ & $\begin{array}{l}\text { Chemical } \\
\text { structure }\end{array}$ \\
\hline 8 & 7.317 & 2.11 & $\begin{array}{l}\text { 4H-Pyran-4-one, 2,3-dihydro-3,5- } \\
\text { dihydroxy-6-methyl- }\end{array}$ & 144.12 & $\mathrm{C}_{6} \mathrm{H}_{8} \mathrm{O}_{4}$ & \\
\hline 9 & 7.967 & 2.14 & 2-Furancarboxaldehyde & 188.18 & $\mathrm{C}_{10} \mathrm{H}_{8} \mathrm{~N}_{2} \mathrm{O}_{3}$ & \\
\hline 17 & 9.700 & 3.77 & 1,3-Propanediol & 76.09 & $\mathrm{C}_{3} \mathrm{H}_{8} \mathrm{O}_{2}$ & \\
\hline 18 & 9.758 & 3.13 & Benzeneacetonitrile & 117.15 & $\mathrm{C}_{8} \mathrm{H}_{7} \mathrm{~N}$ & \\
\hline 23 & 10.725 & 2.38 & 1,2,3,5-Cyclohexanetetrol & 148.16 & $\mathrm{C}_{6} \mathrm{H}_{12} \mathrm{O}_{4}$ & \\
\hline 31 & 12.467 & 5.87 & n-Hexadecanoic acid, methyl ester & 270.45 & $\mathrm{C}_{17} \mathrm{H}_{34} \mathrm{O}_{2}$ & \\
\hline 38 & 13.333 & 19.87 & 6-decenoic acid (Z)- & 170.25 & $\mathrm{C}_{10} \mathrm{H}_{18} \mathrm{O}_{2}$ & \\
\hline 39 & 13.433 & 2.95 & Octadecanoic acid/Stearic acid & 284.5 & $\mathrm{C}_{18} \mathrm{H}_{36} \mathrm{O}_{2}$ & \\
\hline 47 & 14.808 & 2.20 & Cyclohexanecarboxylic acid & 128.17 & $\mathrm{C}_{7} \mathrm{H}_{12} \mathrm{O}_{2}$ & \\
\hline 48 & 14.900 & 11.90 & $\begin{array}{l}\text { 2-Dimethyl(trimethylsilylmethyl) } \\
\text { silyloxymethyltetrahydrofuran }\end{array}$ & 246.49 & $\mathrm{C}_{11} \mathrm{H}_{26} \mathrm{O}_{2}$ & \\
\hline 50 & 15.058 & 6.22 & Malonic acid & 104.06 & $\mathrm{C}_{3} \mathrm{H}_{4} \mathrm{O}_{4}$ & \\
\hline 51 & 15.150 & 2.24 & Docosanoic acid & 340.6 & $\mathrm{C}_{22} \mathrm{H}_{44} \mathrm{O}_{2}$ & \\
\hline 52 & 15.192 & 11.07 & $\begin{array}{l}\text { beta.-1-Rhamnofuranoside, } \\
\text { 5-O-acetyl-thio-octyl- }\end{array}$ & 334.5 & $\mathrm{C}_{16} \mathrm{H}_{30} \mathrm{O}_{5}$ & \\
\hline
\end{tabular}

$\mathrm{RT}=$ retention time.

were the main intracellular nutrient reserves. In contrast to the controls, the micrographs of the treated $B$. cinerea conidia revealed that $M$. oleifera methanol leaf extract at MIC, acts by causing irreversible ultra-structural changes to the conidia (Figures 5b-d). It was observed that the TEM micrographs clearly showed that there were destruction of the organelles and precipitation of the entire cytoplasmic (cytosol) content
(Figures 5b-d). More so, the cell wall was observed to have a slightly irregular shape, shrinked and highly permeable (Figures $5 b$ and d). The external layer of the cell wall was more electrons dense; the plasmalemma was mostly destroyed or did not adhere to the cell wall (Figures 5c-d). It was also observed that there was a reduced periplasmic space between the cell wall and the altered cytoplasm. 
Table 6. Biological activity of different compounds identified in leaf of M. oleifera by GC-MS analysis.

\begin{tabular}{|c|c|c|c|}
\hline Peak No & Chemical compound & Chemical group & Biological activity \\
\hline 8 & $\begin{array}{l}\text { 4H-Pyran-4-one, 2,3-dihydro- } \\
\text { 3,5-dihydroxy-6-methyl- }\end{array}$ & New compound & No activity reported \\
\hline 9 & 2-Furancarboxaldehyde & & $\begin{array}{l}\text { Antimicrobial, Antifungal, } \\
\text { Antioxidant }\end{array}$ \\
\hline 17 & 1,3-Propanediol & - & Antimicrobial \\
\hline 18 & Benzeneacetonitrile & & Cytotoxicity. \\
\hline 23 & 1,2,3,5-Cyclohexanetetrol & - & Cytotoxicity, Antineuropathatic \\
\hline 31 & n-Hexadecanoic acid & Palmitic acid & $\begin{array}{l}\text { Antimicrobial, Antibacterial } \\
\text { Antifungal. Antioxidant, } \\
\text { Nematicide, Antiandrogenic }\end{array}$ \\
\hline 38 & 6-decanoic acid (Z)- & Stearic acid & $\begin{array}{l}\text { Antioxidant, insectifuge, Cancer } \\
\text { preventive. }\end{array}$ \\
\hline 39 & Octadecanoic acid/Stearic acid & Stearic acid & Antimicrobial, Antifungal. \\
\hline 47 & Cyclohexanecarboxylic acid & Aromatic compound & Antimicrobial \\
\hline 48 & $\begin{array}{l}\text { 2-Dimethyl(trimethylsilylmethyl) } \\
\text { silyloxymethyltetrahydrofuran }\end{array}$ & New compound & No activity reported \\
\hline 50 & Malonic acid & Dicarboxylic acid & Antimicrobial Anticancer \\
\hline 51 & Docosanoic acid & Saturated fatty acid & Antioxidant, Antimicrobial \\
\hline 52 & $\begin{array}{l}\text { beta.-1-Rhamnofuranoside, } \\
\text { 5-O-acetyl-thio-octyl- }\end{array}$ & Glycoside & Antimicrobial \\
\hline
\end{tabular}
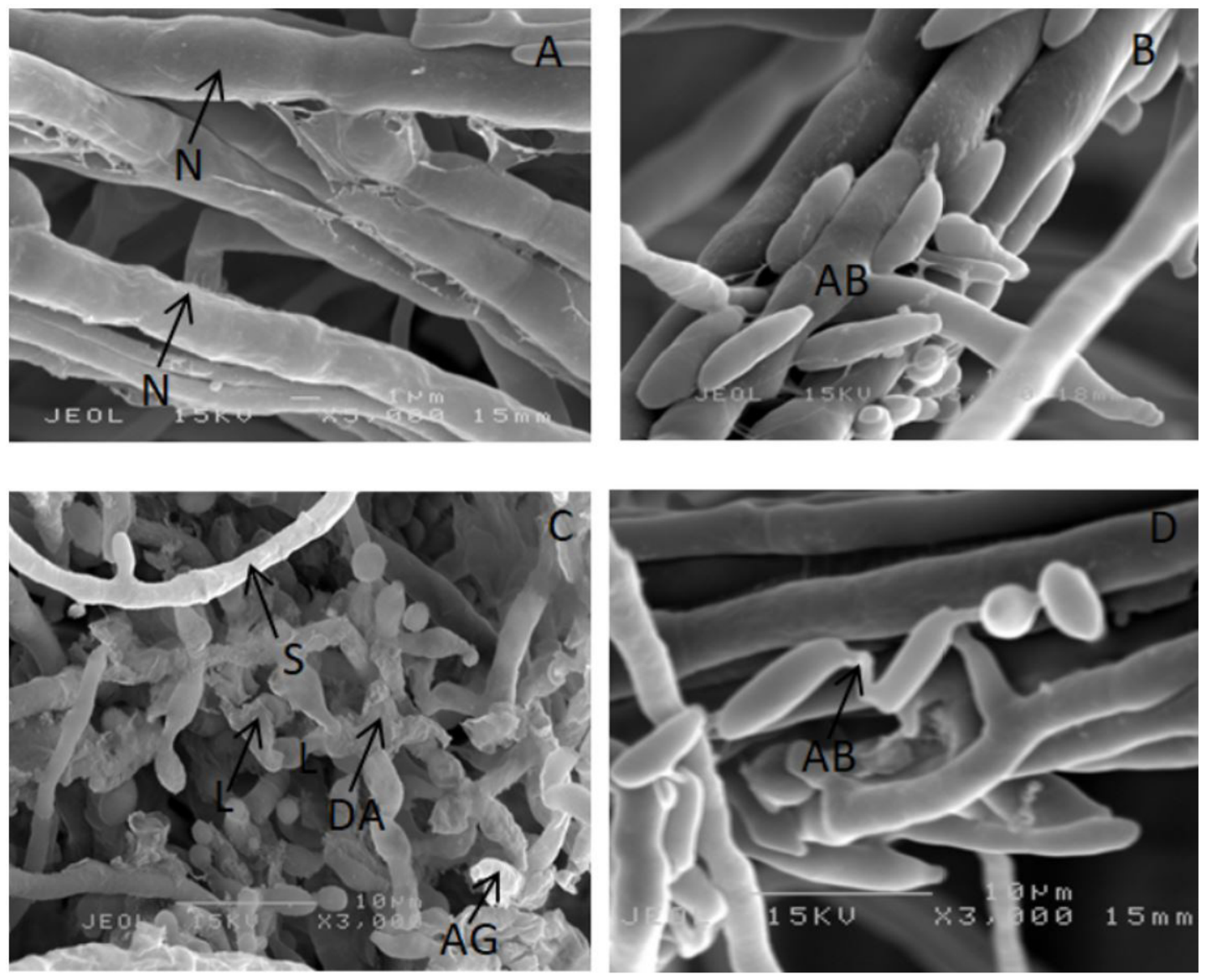

Figure 3. Effect of $M$. oleifera methanol leaf extract on mycelium of B. cinerea. (A) Scanning electron micrographs of control treatment and (B-D) Scanning electron micrographs of treated samples. $\mathrm{N}=$ normal growth and smooth surface; $\mathrm{S}=$ shrinkage; $\mathrm{L}=$ lysis; $\mathrm{AB}=$ abnormal growth; $\mathrm{DA}=$ disruption and aggregation; $\mathrm{AG}=$ aggregation. 
Table 7. Non-volatile active compounds identified in M. oleifera methanol leaf crude extract by LC-MS/MS analysis.

\begin{tabular}{cccllc}
\hline Peak No. & tR/min & $\begin{array}{c}{[\mathbf{M}-\mathbf{H}] \mathbf{( E r r o r}} \\
(\mathbf{p p m}))\end{array}$ & \multicolumn{1}{c}{ Compound name } & $\begin{array}{c}\text { Molecular } \\
\text { formula }\end{array}$ & $\begin{array}{c}\text { Molecular } \\
\text { weight (g/mol) }\end{array}$ \\
\hline 1 & 0.927 & 174.93 & Phenylvaleric acid & $\mathrm{C}_{11} \mathrm{H}_{14} \mathrm{O}_{2}$ & 178.23 \\
2 & 1.210 & 377.25 & Caffeic acid & $\mathrm{C}_{9} \mathrm{H}_{8} \mathrm{O}_{4}$ & 180.16 \\
3 & 1.290 & 191.55 & Quinic acid & $\mathrm{C}_{7} \mathrm{H}_{12} \mathrm{O}_{6}$ & 192.17 \\
10 & 3.433 & 592.61 & Apigenin-6,8-di-C- $\beta$-D- & $\mathrm{C}_{27} \mathrm{H}_{30} \mathrm{O}_{15}$ & 594.52 \\
& & & glucopyranoside (Vicenin II) & $\mathrm{C}_{27} \mathrm{H}_{30} \mathrm{O}_{15}$ & 594.52 \\
11 & 3.998 & 431.60 & Apigenin 6 C glucoside & $\mathrm{C}_{21} \mathrm{H}_{20} \mathrm{O}_{12}$ & 464.38 \\
12 & 4.159 & 928.25 & Quercetin-3-O-glucoside dimer & $\mathrm{C}_{21} \mathrm{H}_{20} \mathrm{O}_{11}$ & 286.24 \\
\hline
\end{tabular}
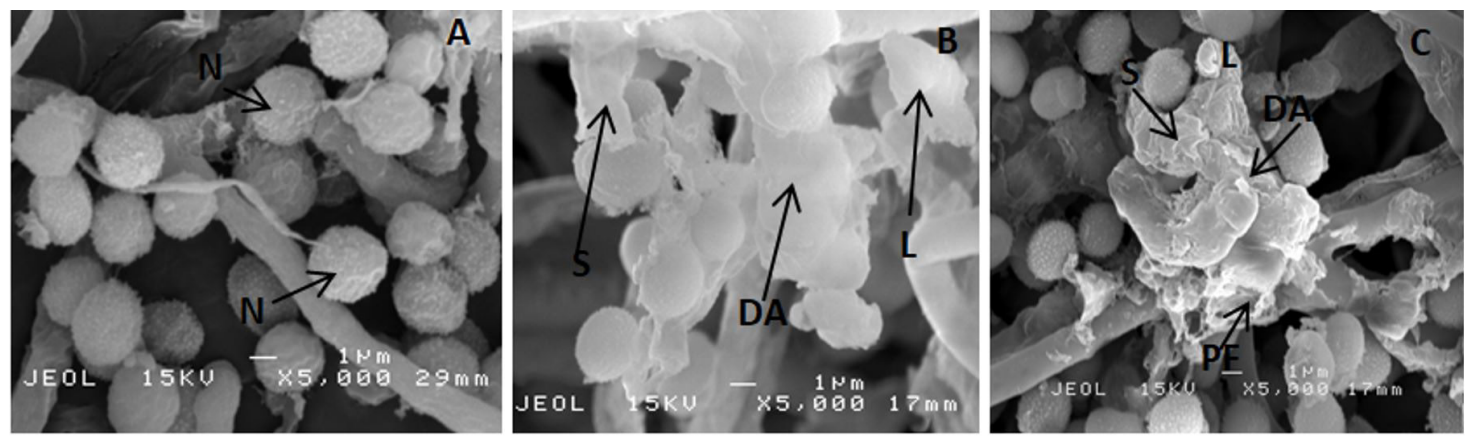

Figure 4. Effect of $M$. oleifera methanol leaf extract on conidia of B. cinerea. (A) Scanning electron micrographs of control treatment and $(\mathbf{B}$ and $\mathbf{C})$ Scanning electron micrographs of treated samples. $\mathrm{N}=$ normal growth and smooth surface; $\mathrm{S}=$ shrinkage; $\mathrm{L}=$ lysis; $\mathrm{DA}=$ disruption and aggregation; $\mathrm{PF}=$ pore formation.
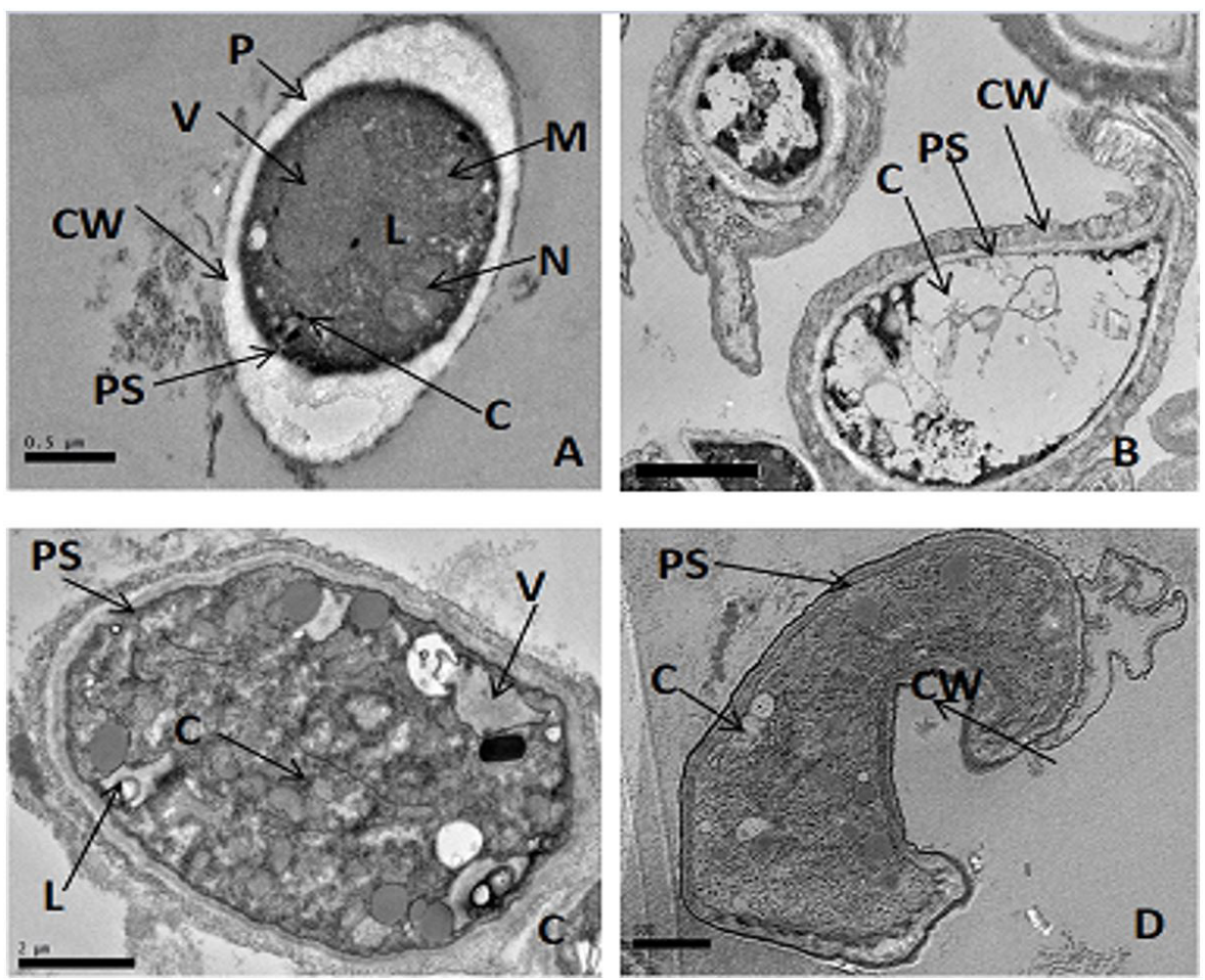

Figure 5. Transmission electron micrograph of treated B. cinerea: (A) Cross section of untreated B. cinerea conidium with the normal ultra-structural components; (B-D) Cross section of B. cinerea conidium treated with $M$. oleifera methanol leaf extract at the minimum inhibitory concentration (MIC) with irreversible ultra-structural changes. $\mathrm{CW}=$ cell wall; $\mathrm{PS}=$ periplasmic space; $\mathrm{P}=$ plasma lemma; $\mathrm{C}=$ cytoplasm; $\mathrm{M}=$ mitochondrion; $\mathrm{V}=$ vacuole $\mathrm{N}=$ nucleus; $\mathrm{L}=$ lipids. 


\section{Discussion}

Moringa oleifera was chosen for this study based on the previous reports that indicated its antifungal and antimicrobial properties effective against various phytopathogens (Emad El Din et al., 2016; Batista et al., 2014; Belay and Sisay, 2014; Díaz Dellavalle et al., 2011). Considering the efficacy of the solvent extracts and the morphological part of the plant used (seeds or leaf), the results on the bioassay showed that organic solvent extracts proved to have high antifungal activity against $B$. cinerea isolates than the aqueous extract irrespective of the morphological part of the plant used. Although, it was noticed that methanol leaf extracts have more antifungal efficacy, in general, organic solvents showed high efficiency in the extraction of water-soluble biomolecules with antifungal activity. However, this could be due the fact that when plant materials were dissolved in the distilled water, some hydrolases and phenolases were released and could have modulating effects on the activity of the active principles in the extracts. Our findings were in accordance with Emad El Din et al. (2016), Gurjar et al. (2012) and Das et al. (2010), who reported that the chemical properties of the solvent, the extraction method used and the various structural and compositional manners of the natural plant products led to extract solvent system with specific differences. Variations in polarity among solvents have been reported to elucidate the differences in solubility of active plant properties, hence differences in the degree of activity (Díaz Dellavalle et al., 2011).

Crude plant extracts are generally a combination of active and non-active compounds. In the present study MIC was obtained at $5 \mathrm{mg} / \mathrm{ml}$ with growth inhibition of up to $100 \%$ comparable to synthetic fungicide benomyl at $0.2 \mathrm{mg} / \mathrm{ml}$ concentration, while the MFC was $10 \mathrm{mg} / \mathrm{ml}$ with $98.10 \%$ growth inhibition. Our results indicated that the MFC of the crude extracts assessed were obtained at higher concentration $(10 \mathrm{mg} / \mathrm{ml})$ than in the MIC assays $(5 \mathrm{mg} / \mathrm{ml})$, but not at lower concentration. This finding agrees with the earlier report of Banso et al. (1999) that indicated that antifungal compounds found in the plant extracts were fungistatic at lower concentrations, while becoming fungicidal at higher concentrations of the extracts. In addition, growth inhibition activity of the crude plant extracts might be due to the synergistic effect of various active compounds that are in higher or small proportion in the crude extract but not due to the action of a single active compound (Rashid et al., 2016; Pinto et al., 2015; Díaz Dellavalle et al., 2011; Banso et al. 1999). In-vitro study on the diametric growth inhibition of the $B$. cinerea isolates by methanol crude extracts of $M$. oleifera has confirmed the antifungal efficacy of the plant. The antifungal activity of the morphological parts of $M$. oleifera found in the reported findings could be as a result of the presence of phenolic compounds, tannins, alkaloids, flavonoids, terpenoids, triterpenoids, saponins (Elad et al., 2016; Pinto et al., 2015; El-Mohamedy and Abdalla, 2014; Tijjani et al., 2014). These phenolic constituents caused the denaturing of enzymes that could impede the amino acids involved in the germination of the spore (Cushnie and Lamb, 2005).

GC-MS analysis of the crude methanol leaf extract was performed and a total of 67 chemical compounds were identified. In comparison with the findings reported previously, most of the compounds identified from this study have also been reported somewhere in other species. For instance, 6-decenoic acid (Z)- was identified as the major compound (19.87\%) of methanol extract of $M$. oleifera leaf and this compound was also reported as a major compound in the methanolic leaves extracts of Clerodendrum viscosum, Indigofera suffruticosa and Trichilia connaroides (Ghosh et al., 2015; Elezabeth and Arumugam 2014), n-hexadecanoic acid in the methanolic leaves extracts of Justicia adhatoda and Lantana camara (Jayapriya and Shoba 2015; Swamy et al., 2015), 2,3-dihydro-3,5-dihydroxy-6-methyl-4H-Pyran-4-one in methanolic extracts of agarwood leaves (Khalil et al., 2013). The identified phytocompounds obtained many biological properties. For example, n-hexadecanoic acid - palmitic acid (R/T 12.467) have biological properties such as an antiandrogenic, antioxidant, antibacterial, hypocholesterolemic, antifungal, nematicide, pesticide and lubricant activities (Mirali et al., 2016; Sermakkani and Thangapandian, 2012). 6-decenoic acid (Z)-acid- Stearic acid (R/T 13.333) was reported to have properties that includes antioxidant, insectifuge and cancer preventive (Elezabeth and Arumugam, 2014).

The analysis of the compounds conducted with LCMS on methanolic leaf extract showed that the major non-volatile constituents of the identified chemical compounds were phenylvaleric acid, caffeic acid, quinic acid, apigenin-6,8-di-C- $\beta$-D-glucopyranoside (Vicenin II), apigenin $6 \mathrm{C}$ glucoside, quercetin-3-O-glucoside dimer and kaempferol 3-o glucoside dimer which are mostly flavones, flavonois and phenolic acids. Previous studies have indicated the protective effects of flavonoids against many infectious and degenerative diseases such as cancers, cardiovascular diseases and other age-related diseases (Khaleel et al., 2016; Kumar and Pandey 2013; Agati et al., 2012). In accordance with previous reports quinic acid was the major chemical constituents in Mussaenda frondosa Linn. with antioxidant and antimicrobial properties (Vadivel and Gopalakrishnan, 2011). Parvu and Parvu (2011) reported the antifungal activity of quercetin-3-O-glucoside and kaempferol 3-o glucoside isolated from Allium fistulosum and $A$. schoenoprasum subsp. schoenoprasum leaves and flowers against B. cinerea, B. paeoniae, A. niger, F. oxysporum f.sp. tulipae, F. oxysporum f. sp. gladioli, Penicillium expansum, P. gladioli, Heterosporium pruneti, and Sclerotinia sclerotiorum.

Botrytis cinerea usually survive in such structures as mycelia and/or conidia and sclerotia in the host plants or their debris. For this reason, we studied the changes that occurred at ultrastructural level in the conidia of $B$. cinerea produced as a result of their exposure at MIC concentration of methanol leaf extract of $M$. oleifera. Under normal circumstances, the cell wall of $B$. cinerea conidia have 
two layers and dark appearance because of the melanin pigment that protects the conidia from ultraviolet light and probably enzymatic action. Furthermore, the $B$. cinerea conidia contain 3 to 18 nuclei (Pacirc et al., 2013; Epton and Richmond, 1980). The surface of $B$. cinerea conidia and other Botrytis spp. have many short protuberances (200 to $250 \mathrm{~nm}$ ) which are visible under SEM and TEM. When being treated at MIC concentration of methanol leaf extract of $M$. oleifera, the shapes and sizes of the mycelia and conidia changed with severe detrimental effects on their morphology which include abnormal growth, lysis, shrinkage, disruption, aggregation, reduced hyphal length and diameters, hypertrophy and pore formation. Similarly, irreversible ultra-structural changes occurred on the conidia that include the destruction of organelles and precipitation of the entire cytoplasmic (cytosol) content, irregular cell wall shape, destruction plasmalemma and a reduced periplasmic space between the cell wall and the altered cytoplasm. Previous studies have indicated that the functional integrity of fungal cell components is needed to keep up its viability and germination quality (Pacirc et al., 2013). However, the precipitation of the cytoplasm and the destruction of the cytoplasmic organelles and nucleus led to the loss of viability and germination quality of $B$. cinerea conidia treated with methanol leaves extract of $M$. oleifera at the MIC concentration. Additionally, the methanol leaf extract caused irreversible changes that abrogate the cell wall's barrier capacity and the possibility of activating enzymes bound to the cell wall (Pacirc et al., 2013; Parvu et al., 2008; Isaac, 1992).

In conclusion, our results showed that methanol leaf extract of $M$. oleifera have strong antifungal efficacy on mycelial growth and spore germination of $B$. cinerea due to severe ultrastructural changes at MIC concentration. Several volatile and non-volatile chemical compounds were identified by GC-MS and LC-MS/MS analysis. Availability of these compounds depends on the organic solvent and the extraction method used. These compounds have been theorised to possess among others, cytotoxicity, antioxidant and antimicrobial properties against $B$. cinerea as confirmed by the results of the present study. The antifungal effect of the studied plant extract recommends it as a promising candidate for biological control of fungal pathogens, thus limiting the overdependence on chemical fungicides.

\section{Acknowledgements}

This project was funded by the Fundamental Research Grant Scheme (FRGS), administered through the Universiti Putra Malaysia (UPM), Ministry of Higher Education, Malaysia (Grant No: UPM/700-2/1/FRGS/07-01-15-1647FR).

\section{References}

ABD-ALLA, M.A. and HAGGAG, W.M., 2010. New safe methods for controlling anthracnose disease of mango (Mangifera indica L.) fruits caused by Colletotrichum gloeosporioides (Penz.). The Journal of American Science, vol. 8, no. 8, pp. 361-366.
AGATI, G., AZZARELLO, E., POLLASTRI, S. and TATTINI, M., 2012. Flavonoids as antioxidants in plants: location and functional significance. Plant Science, vol. 196, pp. 67-76. http:// dx.doi.org/10.1016/j.plantsci.2012.07.014. PMid:23017900.

AIYING, W., BINGGAN, L., TONG, X. and CHAI, L., 2011. Defence responses in tomato fruit induced by oligandrin against Botrytis cinerea. African Journal of Biotechnology, vol. 10, pp. 45954601 .

ALHAKMANI, F., KUMAR, S. and KHAN, S.A., 2013. Estimation of total phenolic content, in-vitro antioxidant and anti-inflammatory activity of flowers of Moringa oleifera. Asian Pacific Journal of Tropical Biomedicine, vol. 3, no. 8, pp. 623-627, discussion 626-627. http://dx.doi.org/10.1016/S2221-1691(13)60126-4. PMid:23905019.

AMADIOHA, A.C., 2002. Fungitoxic effects of extract of Azadirachta indica against Cochliobolus miyabeanus causing brown spot disease of rice. Archives of Phytopathology and Plant Protection, vol. 35, no. 1, pp. 37-42. http://dx.doi.org/10.1080/ 0323540021000009597 .

ANWAR, P., LATIF, S., ASHRAF, M., GYAN, A., 2007. Moringa oleifera: a food plant with multiple medicinal uses. Phytotherapy Research, vol. 21, no. 1, pp. 17-25. http://dx.doi.org/10.1002/ ptr.2023.

ARORA, D.S. and ONSARE, J.G., 2014. In vitro antimicrobial evaluation and phytoconstituents of Moringa oleifera pod husks. Industrial Crops and Products, vol. 52, pp. 125-135. http://dx.doi. org/10.1016/j.indcrop.2013.09.016.

ARORA, D.S., ONSARE, J.M. and KUAR, H., 2013. Bioprospecting of Moringa (Moringaceae): microbiological perspective. Journal of Pharmacognosy and Phytochemistry, vol. 1, no. 6, pp. 193-215.

ARORA, D.S., ONSARE, J.M. and KUAR, H., 2014. Bioprospecting of Moringa (Moringaceae): microbiological perspective. Journal of Pharmacognosy Phytochemistry, vol. 1, no. 6, pp. 193-215.

BANSO, A., ADEYEMO, S.O. and JEREMIAH, P., 1999. Antimicrobial properties of Vernonia amygdalina extract. Journal of Applied Science and Management, vol. 3, pp. 9-11.

BATISTA, A.B., OLIVEIRA, J.T., GIFONI, J.M., PEREIRA, M.L., ALMEIDA, M.G., GOMES, V.M., DA CUNHA, M., RIBEIRO, S.F., DIAS, G.B., BELTRAMINI, L.M., LOPES, J.L., GRANGEIRO, T.B. and VASCONCELOS, I.M., 2014. New insights into the structure and mode of action of $\mathrm{Mo}-\mathrm{CBP}_{3}$, an antifungal chitin-binding protein of Moringa oleifera seeds. PLoS One, vol. 9, no. 10, pp. e111427. http://dx.doi.org/10.1371/ journal.pone.0111427. PMid:25347074.

BELAY, K. and SISAY, M., 2014. Phytochemical constituents and physicochemical properties of medicinal plant (Moringa Oleifera) around bule hora. Chemistry and Materials Research, vol. 6 , no. 7, pp. 61-72.

BROEKAERT, W. F., TERRAS, F. R., CAMMUE, B. P., and VANDERLEYDEN, J., 1990. An automated quantitative assay for fungal growth inhibition. FEMS Microbiology Letters, vol. 69 , no. $1-2$, pp. 55-59.

CÁCERES, A., SARAVIA, A., RIZZO, S., ZABALA, L., DE LEON, E. and NAVE, F., 1992. Pharmacologie properties of Moringa oleifera. 2: screening for antispasmodic, anti-inflammatory and diuretic activity. Journal of Ethnopharmacology, vol. 36, no. 3, pp. 233-237. http://dx.doi.org/10.1016/0378-8741(92)90049-W. PMid:1434682. 
CUSHNIE, T. T. and LAMB, A. J., 2005. Antimicrobial activity of flavonoids. International Journal of Antimicrobial Agents, vol. 2, no. 5, pp. 343-356. https://doi.org/10.1016/j.ijantimicag.2005.09.002.

DAS, K., TIWARI, R.K.S. and SHRIVASTAVA, D.K., 2010. Techniques for evaluation of medicinal plant products as antimicrobial agent: current methods and future trends. Journal of Medicinal Plants Research, vol. 4, no. 2, pp. 104-111.

DEAN, R., VAN KAN, J.A., PRETORIUS, Z.A., HAMMONDKOSACK, K.E., DI PIETRO, A., SPANU, P.D., RUDD, J.J., DICKMAN, M., KAHMANN, R., ELLIS, J. and FOSTER, G.D., 2012. The Top 10 fungal pathogens in molecular plant pathology. Molecular Plant Pathology, vol. 13, no. 4, pp. 414-430. http:// dx.doi.org/10.1111/j.1364-3703.2011.00783.x. PMid:22471698.

DÍAZ DELLAVALLE, P., CABRERA, A., ALEM, D., LARRAÑAGA, P., FERREIRA, F. and DALLA RIZZA, M., 2011. Antifungal activity of medicinal plant extracts against phytopathogenic fungus Alternaria spp. Chilean Journal of Agricultural Research, vol. 71, no. 2, pp. 231-239. http://dx.doi.org/10.4067/S071858392011000200008

DWIVEDI, S.K. and ENESPA, A., 2012. Effectiveness of extract of some medical plants against soil borne fusaria causing diseases on Lycopersicon esculantum and Solanum melongena. International Journal of Pharma and Bio Sciences, vol. 3, pp. 11711180.

ELAD, Y., 2003. Biocontrol of foliar pathogens: mechanisms and application. Communications in Agricultural and Applied Biological Sciences, vol. 68, no. 4 Pt A, pp. 17-24. PMid:15149089.

ELAD, Y., PERTOT, I., COTES PRADO, A.M. and STEWART, A., 2016. Plant hosts of Botrytis spp. In: S. FILLINGER and Y. ELAD, eds. Botrytis - the fungus, the pathogen and its management in agricultural systems. Switzerland: Springer International Publishing, pp. 413-486. http://dx.doi.org/10.1007/978-3-319-23371-0_20.

ELEZABETH, V.D. and ARUMUGAM, S., 2014. GC-MS analysis of bioactive constituents of Indigofera suffruticosa leaves. Journal of Chemical and Pharmaceutical Research, vol. 6, pp. 294-300.

ELLIOTT, M., SHAMOUN, S.F., SUMAMPONG, G., JAMES, D., MASRI, S. and VARGA, A., 2009. Evaluation of several commercial biocontrol products on European and North American populations of Phytophthora ramorum. Biocontrol Science and Technology, vol. 99, no. 10, pp. 1007-1021. http://dx.doi. org/10.1080/09583150903243870.

EL-MOHAMEDY, R.S.R. and ABDALLA, A.M., 2014. Evaluation of antifungal activity of Moringa oleifera extracts as natural fungicide against some plant pathogenic fungi In-vitro. Agricultural Technology (Thailand), vol. 10, no. 4, pp. 963-982.

EMAD EL DIN, G.G., ESMAIEL, N., SALEM, M.Z. and GOMAA, S.E., 2016. In vitro screening for antimicrobial activity of some medicinal plant seed extracts. Biotechnology for Wellness Industries, vol. 5, no. 4, pp. 142-152. http://dx.doi. org/10.6000/1927-3037.2016.05.04.4.

ENYIUKWU, D.N., AWURUM, A.N. and NWANERI, J.A., 2014. Efficacy of plant-derived pesticides in the control of myco-induced postharvest rots of tubers and agricultural products: a review. Net Journal of Agricultural Science, vol. 2, no. 1, pp. 30-46.

EPTON, H.A.S. and RICHMOND, D.V., 1980. Formation, structure and germination of conidia. In: J.R. COLEY-SMITH, K. VERHOEFF and W.R. JARVIS, eds. The biology of Botrytis. London: Academic Press, pp. 41-83.

GAO, X., XIE, M., LIU, S., GUO, X., CHEN, X., ZHONG, Z., WANG, L. and ZHANG, W., 2014. Chromatographic fingerprint analysis of metabolites in natural and artificial agarwood using gas chromatography-mass spectrometry combined with chemometric methods. Journal of Chromatography. B, Analytical Technologies in the Biomedical and Life Sciences, vol. 967, pp. 264-273. http:// dx.doi.org/10.1016/j.jchromb.2014.07.039. PMid:25129412.

GHANI, A., 1998. Medicinal plants of Bangladesh. Dhaka: Asiatic Society of Bangladesh, pp. 78-83.

GHOSH, G., PANDA, P., RATH, M., PAL, A., SHARMA, T. and DAS, D., 2015. GC-MS analysis of bioactive compounds in the methanol extract of Clerodendrum viscosum leaves. Pharmacognosy Research, vol. 7, no. 1, pp. 110-113. http://dx.doi. org/10.4103/0974-8490.147223. PMid:25598644.

GIFONI, J.M., OLIVEIRA, J.T., OLIVEIRA, H.D., BATISTA, A.B., PEREIRA, M.L., GOMES, A.S., OLIVEIRA, H.P., GRANGEIRO, T.B. and VASCONCELOS, I.M., 2012. A novel chitin-binding protein from Moringa oleifera seed with potential for plant disease control. Peptide Science, vol. 98, no. 4, pp. 406-415. http://dx.doi.org/10.1002/bip.22068. PMid:23193603.

GURJAR, M.S., ALI, S., AKHTAR, M. and SINGH, K.S., 2012. Efficacy of plant extracts in plant disease management. Agricultural Sciences, vol. 3, no. 3, pp. 425-433. http://dx.doi. org/10.4236/as.2012.33050.

HARBONE, J.B., 2001. Phytochemical methods. London: Chapman and Hall Ltd, 113 pp

HASAN, S., SINGH, K., DANISUDDIN, M., VERMA, P.K. and KHAN, A.U., 2014. Inhibition of major virulence pathways of Streptococcus mutans by quercitrin and deoxynojirimycin: A synergistic approach of infection control. PLoS One, vol. 9, no. 3, pp. e91736. http://dx.doi.org/10.1371/journal.pone.0091736. PMid:24622055.

HOLLOMON, D.W., 2015. Fungicide resistance. 40 years on and still a major problem. In H. ISHII and D. HOLLOMON, eds. Fungicide resistance in plant pathogens. Tokyo: Springer, pp. 3-11. http://dx.doi.org/10.1007/978-4-431-55642-8 1.

ISAAC, S., 1992. Fungal-plant interactions. London: Chapman $\&$ Hall

ISHII, H. and HOLLOMAN, D.W., 2015. Fungicide resistance in plant pathogens. Tokyo: Springer. http://dx.doi.org/10.1007/9784-431-55642-8.

JAYAPRIYA, G. and SHOBA, F.G., 2015. GC-MS analysis of bio-active compounds in methanolic leaf extracts of Justicia adhatoda (Linn.). Journal of Pharmacognosy and Phytochemistry, vol. 4, pp. 113-117.

KADHIM, E.J. and AL-SHAMMAA, D.A., 2014. Phytochemical characterisation using GC-MS analysis of methanolic extract of Moringa oleifera (Moringaceae) plant cultivated in Iraq. Chemistry and Materials Research, vol. 6, no. 5, pp. 9-26.

KARNOVSKY, M.J., 1965. A formaldehyde-glutaraldehyde fixative of high osmolality for use in electron microscopy. The Journal of Cell Biology, vol. 27, pp. 137-138.

KARS, I., MCCALMAN, M., WAGEMAKERS, L. and VAN KAN, J.A., 2005. Functional analysis of Botrytis cinerea pectin methylesterase genes by PCR-based targeted mutagenesis: Bcpme1 and Bcpme2 are dispensable for virulence of strain B05.10. Molecular Plant Pathology, vol. 6, no. 6, pp. 641-652. http:// dx.doi.org/10.1111/j.1364-3703.2005.00312.x. PMid:20565686.

KHALEEL, A.I., SIJAM, K., RASHID, T.S. and BIN AHMAD, K., 2016. Phytochemical determination and antibacterial activity of 
Punica granatum peel extracts against plant pathogenic bacteria. American Journal of Plant Sciences, vol. 7, no. 1, pp. 159-166. http://dx.doi.org/10.4236/ajps.2016.71017.

KHALIL, A.S., RAHIM, A.A., TAHA, K.K. and ABDALLAH, K.B., 2013. Characterization of methanolic extracts of agarwood leaves. Journal of Applied and Industrial Sciences, vol. 1, no. 3, pp. 78-88.

KIM, J.O., SHIN, J.H., GUMILANG, A., CHUNG, K., CHOI, K. Y., and KIM, K. S., 2016. Effectiveness of different classes of fungicides on Botrytis cinerea causing gray mold on fruit and vegetables. The Plant Pathology Journal, vol. 32, no. 6, pp. 570574. https://dx.doi.org/10.5423/PPJ.NT.05.2016.0114.

KRISHNAMURTHY, P.T., VARDARAJALU, A., WADHWANI, A. and PATEL, V., 2015. Identification and characterization of a potent anticancer fraction from the leaf extracts of Moringa oleifera L. Indian Journal of Experimental Biology, vol. 53, no. 2, pp. 98-103. PMid:25757240.

KUMAR, S. and PANDEY, A.K., 2013. Chemistry and biological activities of flavonoids: an overview. The Scientific World Journal, vol. 2013, pp. 1-16. http://dx.doi.org/10.1155/2013/162750.

LI DESTRI NICOSIA, M.G., PANGALLO, S., RAPHAEL, G., ROMEO, F.V., STRANO, M.C., RAPISARDA, P., DROBY, S. and SCHENA, L., 2016. Control of postharvest fungal rots on citrus fruit and sweet cherries using a pomegranate peel extract. Postharvest Biology and Technology, vol. 114, pp. 54-61. http:// dx.doi.org/10.1016/j.postharvbio.2015.11.012.

LOURENS, A. C. U., REDDY, D., BAŞER, K. H. C., VILJOEN, A. M., and VAN VUUREN, S. F., 2004. In-vitro biological activity and essential oil composition of four indigenous South African Helichrysum species. Journal of Ethnopharmacology, vol. 95, no. 2-3, pp. 253-258. http://dx.doi.org/10.1016/j.jep.2004.07.027.

MAKOVITZKI, A., VITERBO, A., BROTMAN, Y., CHET, I. and SHAI, Y., 2007. Inhibition of fungal and bacterial plant pathogens in vitro and in planta with ultrashort cationic lipopeptides. Applied and Environmental Microbiology, vol. 73, no. 20, pp. 6629-6636. http://dx.doi.org/10.1128/AEM.01334-07. PMid:17720828.

MBIKAY, M., 2012. Therapeutic potential of Moringa oleifera leaves in chronic hyperglycemia and dyslipidemia. a review. Frontiers in Pharmacology, vol. 3, pp. 24. http://dx.doi.org/10.1128/ AEM.01334-07.

MIRALI, M., PURVES, R.W., STONEHOUSE, R., SONG, R., BETT, K. and VANDENBERG, A., 2016. Genetics and biochemistry of zero-tannin lentils. PLoS One, vol. 11, no. 10, pp. e0164624. http://dx.doi.org/10.1371/journal.pone.0164624. PMid:27788158.

MUSHORE, J. and MATUVHUNYE, M., 2013. Antibacterial properties of Mangifera indica on Staphylococcus aureus. African Journal of Clinical and Experimental Microbiology, vol. 14, no. 2, pp. 62-74. http://dx.doi.org/10.4314/ajcem.v14i2.4.

PACIRC, M., PACIRC, A.E., BARBU-TUDORAN, L., ROŞCACASIAN, O., VLASE, L., DANCIU, M.R. and PACIRC, O., 2013. In-vitro effects of Allium obliquum extract on the growth and ultrastructure of Botrytis paeoniae. Journal of Medicinal Plants Research, vol. 7, no. 17, pp. 1138-1145.

PÂRVU, M. and PÂRVU, A.E., 2011. Antifungal plant extracts. Science against microbial pathogens: Communicating current research and technological advances. Badajoz: Formatex Research Center, pp. 1055-1062.

PARVU, M., PÂRVU, A.E., CRĂCIUN, C., BARBU-TUDORAN, L. and TĂMAŞ, M., 2008. Antifungal activities of Chelidonium majus extract on Botrytis cinerea in-vitro and ultrastructural changes in its conidia. Journal of Phytopathology, vol. 156, no. 9 , pp. 550-552. http://dx.doi.org/10.1111/j.1439-0434.2008.01410.x.

PARVU, M., PARVU, A.E., CRACIUN, C., BARBU-TUDORAN, L., VLASE, L., TAMAS, M. and MOLNAR, A.M., 2010. Changes in Botrytis cinerea conidia caused by Berberis vulgaris extract. Notulae Botanicae Horti Agrobotanici Cluj-Napoca, vol. 38, no. 3, pp. 15-20. http://dx.doi.org/10.15835/nbha3834741.

PINTO, C.E., FARIAS, D.F., CARVALHO, A.F., OLIVEIRA, J.T., PEREIRA, M.L., GRANGEIRO, T.B., FREIRE, J.E., VIANA, D.A. and VASCONCELOS, I.M., 2015. Food safety assessment of an antifungal protein from Moringa oleifera seeds in an agricultural biotechnology perspective. Food and Chemical Toxicology, vol. 83, pp. 1-9. http://dx.doi.org/10.1016/j. fct.2015.05.012. PMid:26032632.

RASHID, T.S., SIJAM, K., KADIR, J., SAUD, H.M., AWLA, H.K., ZULPERI, D. and HATA, E.M., 2016. Screening for active compounds in Rhus coriaria L. crude extract that inhibit the growth of Pseudomonas syringae and Ralstonia solanacearum. Indian Journal of Agricultural Research, vol. 50, no. 1, pp. 15-21. http://dx.doi.org/10.18805/ijare.v50i1.8583.

REYNOLDS, E.S., 1963. The use of lead citrate at high $\mathrm{pH}$ as an electron-opaque stain in electron microscopy. The Journal of Cell Biology, vol. 17, no. 1, pp. 208-212. http://dx.doi.org/10.1083/ jcb.17.1.208. PMid:13986422.

SASIDHARAN, S., YOGA, L., YUET, K. and JOTHY, S., 2012. Screening methods in the study of fungicidal property of medicinal plants. In: D. DHANASEKARAN, ed. Fungicides for plant and animal diseases. London: IntechOpen, pp. 107-118. http://dx.doi. org/10.5772/25714.

SATISH, A., PUNITH KUMAR, R., RAKSHITH, D., SATISH, S. and AHMED, F., 2013. Antimutagenic and antioxidant activity of Ficus benghalensis stem bark and Moringa oleifera root extract. International Journal of Chemical and Analytical Science, vol. 4, no. 2, pp. 45-48. http://dx.doi.org/10.1016/j.ijcas.2013.03.008.

SATISH, S., MOHANA, D.C., RANHAVENDRA, M.P. and RAVEESHA, K.A., 2007. Antifungal activity of some plant extracts against important seed borne pathogens of Aspergillus sp. Agricultural Technology (Thailand), vol. 3, no. 1, pp. 109-119.

SERMAKKANI, M. and THANGAPANDIAN, V., 2012. GC-MS analysis of Cassia italica leaf methanol extract. Asian Journal of Pharmaceutical and Clinical Research, vol. 5, no. 2, pp. 90-94.

SHARMA, V. and PALIWAL, R., 2013. Isolation and characterization of saponins from Moringa oleifera (Moringaceae) pods. International Journal of Pharmacy and Pharmaceutical Sciences, vol. 5, no. 1, pp. 179-183.

SHAW, M.W., EMMANUEL, C.J., EMILDA, D., TERHEM, R.B., SHAFIA, A., TSAMAIDI, D., EMBLOW, M. and VAN KAN, J.A., 2016. Analysis of cryptic, systemic Botrytis infections in symptomless hosts. Frontiers in Plant Science, vol. 7, pp. 625. http://dx.doi.org/10.3389/fpls.2016.00625. PMid:27242829.

SOFOWORA, A., 2005. Medicinal plants and traditional medicine in Africa. Ibadan, Nigeria: Spectrum Books Ltd, 289 pp.

STAATS, M., VAN BAARLEN, P. and VAN KAN, J.A.L., 2005. Molecular phylogeny of the plant pathogenic genus Botrytis and the evolution of host specificity. Molecular Biology and Evolution, 
vol. 22, no. 2, pp. 333-346. http://dx.doi.org/10.1093/molbev/ msi020. PMid: 15496556

SWAMY, M.K., SINNIAH, U.R. and AKHTAR, M.S., 2015. In vitro pharmacological activities and GC-MS analysis of different solvent extracts of Lantana camara leaves collected from tropical region of Malaysia. Evidence-Based Complementary and Alternative Medicine, vol. 2015, pp. 506413. http://dx.doi. org/10.1155/2015/506413. PMid:26783409.

TAIGA, A., SULEIMAN, M. N. W. and OLUFOLAJI D, B., 2008. Comparative in vitro inhibitory effects of cold extracts of some fungicidal plants on Fusarium oxysporium mycelium. African Journal of Biotechnology, vol. 7, no. 18, pp. 3306-3308.

TIJJANI, A., ADEBITAN, S.A., GURAMA, A.U., HARUNA, S.G. and SAFIYA, T., 2014. Effect of some selected plant extracts on Aspergillus flavus, a causal agent of fruit rot disease of tomato (Solanum lycopersicum) in Bauchi State. International Journal of Biosciences, vol. 4, no. 2, pp. 244-252. http://dx.doi.org/10.12692/ $\mathrm{ijb} / 4.12 .244-252$.

TIJJANI, A., KHAIRULMAZMI, A., SITI, I.I. and DZOLKHIFLI, O., 2016. Pathogenicity assay and molecular identification of Botrytis cinerea isolates causing gray mold on tomato in Malaysia.
In: Proceedings of the 7th International Agricultural Congress, 2016, Malaysia. Malaysia: ITAFoS, pp. 241-248.

VADIVEL, E. and GOPALAKRISHNAN, S., 2011. GC-MS analysis of some bioactive constituents of Mussaenda frondosa Linn. International Journal of Pharma and Bio Sciences, vol. 2, pp. 313-320

VERMA, A.R., VIJAYAKUMAR, M., MATHELA, C.S. and RAO, C.V., 2009. In-vitro and in-vivo antioxidant properties of different fractions of Moringa oleifera leaves. Food and Chemical Toxicology, vol. 47, no. 9, pp. 2196-2201. http://dx.doi. org/10.1016/j.fct.2009.06.005. PMid:19520138.

VONGSAK, B., SITHISARN, P. and GRITSANAPAN, W., 2014. Simultaneous HPLC quantitative analysis of active compounds in leaves of Moringa oleifera Lam. Journal of Chromatographic Science, vol. 52, no. 7, pp. 641-645. http://dx.doi.org/10.1093/ chromsci/bmt093. PMid:23828911.

WILLIAMSON, B., TUDZYNSKI, B., TUDZYNSKI, P. and VAN KAN, J.A., 2007. Botrytis cinerea: The cause of grey mold disease. Molecular Plant Pathology, vol. 8, no. 5, pp. 561-580. http://dx.doi.org/10.1111/j.1364-3703.2007.00417.x. PMid:20507522. 